\title{
Kohesi Wacana Dalam Kumpulan Puisi Berguru Kepada Rindu Karya Acep Zamzam Noor
}

\author{
Rizki Joko Nurcahyo ${ }^{1}$ \\ Viana Nandasari ${ }^{1}$ \\ Rifa Dewi Zulaikha ${ }^{1}$ \\ ${ }^{1}$ Institut Agama Islam Negeri \\ Surakarta, Surakarta, Jawa Tengah, \\ Indonesia \\ *email: rizkijoko9@gmail.com
}

Received: 10 Desember 2019

Accepted: 26 Maret 2020

Published: 26 Maret 2020

doi:

http://dx.doi.org/10.29405/imj.v2i2 .55

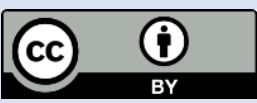

(C) 2020 Oleh authors. Lisensi Imajeri: Jurnal Pendidikan Bahasa dan Sastra Indonesia, Uhamka, Jakarta. Artikel ini bersifat open access yang didistribusikan di bawah syarat dan ketentuan Creative Commons Attribution (CC-BY) license. (http://creativecommons.org/licens es/by/4.0/)

\begin{abstract}
Abstrak
Puisi diartikan sebagai salah satu bentuk karya sastra yang dikategorikan ke dalam sebuah struktur wacana yang utuh, sehinga dalam pemakaian bahasanya harus mengikuti dan selaras dengan berkembangnya suatu zaman. Penelitian ini bertujuan untuk menganalisis dan mendeskripsikan penggunaan kohesi gramatikal dan penggunaan kohesi leksikal yang terdapat dalam Kumpulan Puisi "Berguru Kepada Rindu" Karya Acep Zamzam Noor. Teori yang digunakan dalam penelitian ini adalah teori jenis kohesi wacana milik Sumarlam.Metode penelitian yang digunakan dalam penelitian ini adalah metode penelitian kualitatif. Data dalam penelitian ini berasal dari bait-bait dalam kumpulan puisi "Berguru Kepada Rindu" karya Acep Zamzam Noor. Teknik pengumpulan data dalam penelitian ini adalah teknik purpose sampling. Analaisis data dilakukan dengan cara mengklasifikasikan pirantipiranti kohesi dalam sebuah wacana menggunakan teori yang dikemukakan Sumarlam. Berdasarkan temuan data-data yang dianalisis, piranti kohesi yang paling dominan yang terdapat pada Buku Kumpulan Puisi "Berguru Kepada Rindu" Karya Acep Zamzam Noor adalah piranti kohesi leksikal.
\end{abstract}

Kata kunci: Wacana; kohesi; leksikal; gramatikal; puisi.

\section{Abstract}

Poetry is defined as a form of literary work which is categorized into a whole structure of discourse, so that the use of the language must follow and be in line with the development of an era. This study aims to analyze and describe the use of grammatical cohesion and the use of lexical cohesion contained in the Collection of Poetry "Learn to Miss" by Acep Zamzam Noor. The theory used in this research is Sumarlam's discourse cohesion type theory. The research method used in this study is a qualitative research method. The data in this study come from the verses in a collection of poems "Berguru To Rindu" by Acep Zamzam Noor. Data collection techniques in this study are purpose sampling techniques. Data analysis is done by classifying cohesion devices in a discourse using the theory proposed by Sumarlam. Based on the findings of the analyzed data, the most dominant cohesion tool contained in the Book of Poetry Collection "Learn to Miss" by Acep Zamzam Noor is a lexical cohesion tool

Keywords: Discourse; cohesio; lexical; grammatical; poetry.

\section{PENDAHULUAN}

Wacana merupakan satuan terlengkap dalam suatu bahasa. Sedangkan analisis wacana diartikan sebagai sebuah kajian yang digunakan untuk menganilisis atau mengkaji bahasa yang digunakan manusia secara alamiah untuk berkomunikasi baik dalam bentuk lisan maupun tulisan. (Stubs dalam Badara, 2012). Oleh karena itu, apabila dilihat dari struktur lahirnya (dari segi bentuk) wacana bersifat kohesif yang berarti saling terkait. Namun, apabila dilihat dari struktur batinnya (dari segi makna) wacana bersifat koherensif, dan terpadu. 
Sehingga dalam proses komunikasi atau penyampaian informasi dapat diterima secara rinci dan jelas.

Menurut Mulyana ( 2005) wacana dapat dikatakan sebagai wacana yang lengkap apabila wacana tersebut mengandung aspek kepaduan dan menyatu baik dari penanda kohesi maupun koherensi. Rani (2004) menjelaskan bahwa kohesi memiliki konsep yang diacukan pada kesatuan hubungan yang erat untuk membentuk sebuah kepaduan. Maksudnya, di dalam sebuah wacana, kohesi memiliki beberapa unsure yang berupa kata, frasa, klausa, dan kalimat yang digunakan sebagai alat penyusun suatu wacana yang utuh. Selain itu, Halliday dalam Sumarlam (2003) mengemukakan bahwa wacana sangat bergantung dpada unsur lain dalam sebuah wacana, artinya meskipun wacana berada dalam tataran tertinggi, akan tetapi, wacana masih membutuhkan unsur lain sebagai aspek pedukung dan penjelas. Unsur-unsur kohesi wacana tersebut digolongkan menjadi dua jenis, yaitu kohesi gramatikal dan kohesi leksikal.

Sumarlam (2003) menjelaskan bahwa wacana terbagi menjadi dua, yaitu wacana lisan dan wacana tulis. Wacana lisan merupakan wacana yang disampaikan secara lisan misalnya ceramah, khotbah, pidato dan dialog. Sedangkan wacana tulis merupakan wacana yang disampaikan secara tertulis misalnya dokumen tertulis, cerpen, novel, buku surat, dan puisi.

Di dalam wacana tulis, secara tidak langsung akan terjadi adanya komunikasi antara penulis dengan pembaca. Oleh karena itu, keberadaan kohesi sangat penting perann ya dalam membangun komunikasi yang baik, benar, dan jelas untuk para pembacanya. Apabila sebuah wacana memiliki kohesi yang baik, maka sudah dapat dikatakan bahwa wacana yang dihasilkan akan mudah untuk dipahami oleh pembacanya. Pesan yang akan disampaikan oleh penulis kepada pembaca pun akan tersampaikan dengan baik pula. Sehingga wacana tersebut dapat dikatakan sebagai wacana yang baik. Kohesi dalam suatu wacana sangat diperlukan dan tentunya sangat diperhatikan dalam menulis sebuah wacana tulis misalnya wacana puisi.

Puisi merupakan salah satu bentuk karya sastra yang eksistensinya tidak pernah lekang ditelan zaman. Puisi menjadi salah satu karya sastra yang eksis dan banyak digemari para pembaca karena kepadatan kata dan keluasan makna yang terkandung dalam puisi tersebut. Selain itu, puisi juga dapat diartikan sebagai salah satu bentuk karya sastra yang dikategorikan ke dalam sebuah struktur wacana yang utuh, sehinga dalam pemakaian bahasanya harus mengikuti dan selaras dengan berkembangnya suatu zaman (Purwitosari, 2010). Oleh karena itu, puisi dapat dikaji dan ditelaah dari sudut pandang wacananya.

Salah satu puisi yang menarik untuk dikaji adalah puisi yang berjudul Berguru Kepada Rindu karya Acep Zamzam Noor yang merupakan puisi yang di dalamnya menonjolkan unsur suasana yang syahdu, yang setiap uraian katanya merangsang pembacanya untuk berimajinasi. Dalam puisi-puisi tersebut didominasi oleh puisi yang bertemakan cinta dan alam yang sangat menyentuh pembacanya. Sehingga dalam hal ini, penyair mempunyai nilai lebih pada buku kumpulan puisinya dibandingkan dengan buku kumpulan puisi milik orang lain. Selain itu, cara penyampaian puisi ini pun begitu khas dengan kata-kata yang singkat yang dipadatkan tetapi maknanya tetap utuh dan indah. Oleh karena itu, penulis tertarik untuk meneliti kata-kata dalam wacana puisi tersebut dalam aspek kata penanda kohesi leksikal dan kohesi gramatikal.

Penelitian yang akan dilakukan ini relevan dengan beberapa penelitian yang terdahulu. Pertama, penelitian pada jurnal metalingua yang dilakukan oleh (Herianah, 2014) dengan judul Kohesi Gramatikal dan Leksikal dalam Wacana Puisi Tadarusku Untukmu. Persamaan penelitian ini dengan penelitian yang penulis teliti adalah sama-sama menganalisis kohesi wacana dalam sebuah wacana tulis puisi. Sedangkan perbedaannya adalah objek yang akan dikaji. Penelitian ini mengkaji Puisi Tadarusku Untukmu, sedangkan peneliti mengkaji Kumpulan Puisi "Berguru Kepada Rindu” Karya Acep Zamzam Noor.Kedua, penelitian jurnal yang dilakukan oleh (Ika Merry Romadhani, 2016) dengan judul Kohesi Gramatikal 
pada Kumpulan Puisi Geladi Diri dan Implikasinya dalam Pembelajaran bahasa di SMP. Persamaan penelitian ini dengan penelitian yang penulis teliti adalah sama-sama menganalisis kohesi wacana dalam sebuah wacana tulis puisi. Sedangkan perbedaannya adalah objek yang akan dikaji. Penelitian ini mengkaji Kumpulan Puisi Geladi Diri, sedangkan peneliti mengkaji Kumpulan Puisi “Berguru Kepada Rindu” Karya Acep Zamzam Noor.

Berdasarkan latar belakang yang telah diuraikan di atas, maka penulis mengangkat penelitian dengan judul Kohesi Wacana dalam Kumpulan Puisi "Berguru Kepada Rindu" Karya Acep Zamzam Noor. Penelitian ini bertujuan untuk menganalisis dan mendeskripsikan penggunaan kohesi gramatikal dan kohesi leksikal pada buku Kumpulan Puisi "Berguru Kepada Rindu” Karya Acep Zamzam Noor.

\section{METODE}

Metode penelitian yang digunakan dalam penelitian ini adalah metode kualitatif. Metode kualitatif yaitu metode penelitian yang bertujuan untuk mendeskripsikan secara sistematis, faktual, dan akurat mengenai fakta-fakta, sifat-sifat, serta hubungan fenomena yang satu dengan fenomena lain yang telah diselidiki (Inderasari, 2017). Data dalam penelitian ini berasal dari bait-bait dalam kumpulan puisi "Berguru Kepada Rindu" karya Acep Zamzam Noor. Dalam penelitian ini, Teknik pengumpulan data yang digunakan adalah teknik purpose sampling. Selain itu, penelitian ini termasuk dalam jenis penelitian kualitatif sehingga data yang terkumpul dianalisis menggunakan analisis kualitatif yaitu data yang dianalisis berupa kata-kata bukan angka. Analaisis data dilakukan dengan cara mengklasifikasikan piranti-piranti kohesi dalam sebuah wacana menggunakan teori yang dikemukakan Sumarlam (2003) yaitu piranti kohesi wacana digolongkan menjadi dua jenis yaitu piranti kohesi gramatikal dan kohesi leksikal.

\section{HASIL DAN PEMBAHASAN}

Pada bab ini akan dibahas mengenai piranti kohesi yang terdapat dalam buku kumpulan puisi "Berguru Kepada Rindu" karya Acep Zamzam Noor menggunakan pendapat Sumarlam (2003)mengenai piranti kohesi dalam sebuah wacana. Sumarlam (2003) membagi piranti kohesi wacana menjadi dua jenis yaitu piranti kohesi gramatikal dan piranti kohesi leksikal.

\section{Piranti Kohesi Gramatikal}

Kohesi gramatikal merupakan keterkaitan antara bagian wacana secara gramatikal, yaitu bentuk-bentuk kohesi yang dinyatakan melalui sebuah tat bahasa. Sumarlam (2003: 35) menjelaskan bahwa dalam analisis wacana, dilihat dari struktur lahirnya, wacana disebut sebagai aspek gramtikal yang memiliki beberapa pemarkah seperti referensi, substitusi, elipsis dan konjungsi.

\section{a. Referensi (Pengacuan)}

Referensi menurut Sumarlam ( 2003: 4) yaitu jenis kohesia gramatikal yang terdiri atas satuan lingual yang mengacu pada satuan lingual lainnya. Dalam bahasa Indonesia dikenal tiga macam pronomina, antara lain pronomina persona, pronomina demonstratif, dan pronomina komparatif. Berikut pembahasan dari ketiga pronomina tersebut.

\section{Pronomina Persona}

Pronomina Persona adalah kata ganti yang biasanya digunakan untuk menunjukkan kata ganti orang. Berikut data penggunaan pronomina persona.

\section{Data 1}

Tak lagi pergi harimu 
Tak lagi datang malammu

Di tubuhmu

(Noor, 2017:16)

Data di atas menunjukkan pronomina persona kedua, terbukti pada kata -mu di akhir baris. Kata ganti orang kedua kerap digunakan untuk memanggil lawan bicara.

\section{Data 2}

Tidak setiap senja aku bisa menemukan

Tidak setiap senja aku mampu menerima

(Noor, 2017: 22)

Data di atas menunjukkan pronomina persona pertama berupa kata aku.Ciriciri katagantiakudigunakandalamkalimat perkataan yang sifatnyatidak formal.

\section{Data 3}

Alis matamu mengiris lengkung pantai yang kehitaman

Dari mulut biru. Pelipismu memantulkan paras langit

Di sela rambutmu yang hijau

Dan matahari menebarkan kilau emasnya pada kulitmu

Dari seluruh keindahanmu

Ke balik gaun suteramu

(Noor, 2017: 71)

Data di atas menunjukkan pronomina persona kedua, terbukti pada kata -mu di akhir baris. Kata ganti orang kedua kerap digunakan untuk memanggil lawan bicara.

\section{Pronomina Demonstratif}

Pronomina demonstratif adalah kata yang menerangkan letak tempat beradanya suatu benda atau yang dibendakan. Biasanya menggunakan kata ini dan itu. Berikut data penggunaan pronomina demonstratif.

\section{Data 4}

Sebab pantai demi pantai tak pernah membuatku sampai

Langkah selalu terantuk pada tebing atau jurang itu juga

Berdasarkan data di atas, terdapat kata itu yang menunjukkan pronomina demonstratif tunggal yang mengacu pada kata sebelumnya yaitu Sebab pantai demi pantai tak pernah membuatku sampai.

b. Penggantian (Substitusi)

Sumarlam (2003: 28) menyatakan bahwa substitusi merupakansatu di antara jenis kohesi gramatikal yang berupa penggantian perangkat lingual dengan perangkat lingual lainnya dalam suatu bahasa guna mendapatkan unsur pembeda. Secara umum, penggantian (substitusi) berupa Substitusi Nomina, Substitusi Frasa, dan Substitusi Klausa.

\section{Subtitusi Nomina}

Subtitusi nomina adalah penggantian satuan lingual yang berkategori nomina dengan satuan lingual yang berkategori sama.

\section{Data 5}

Di balik keremangan senja tinggal matamu

Yang masih kutandai sebagai titik cahaya

Alun ombak terus bergerak menyeret perahu

Yang ujung lunasnya mulai rapuh tergerus air

(Noor, 2017: 65) 
Data diatas menunjukan penggunaan penggantian kata matamu dengan kata titik cahaya hal tersebut dilakukan untuk memberikan unsur pembeda.

\section{Subtitusi Frasa}

Subtitusi frasa adalah penggantian perangkat lingual berupa kata ataufrasadengan perangkat lingual lainnya yang berupafrasa.

\section{Data 6}

Di matamu aku bukanlah ksatria

Dengan baju zirah dan kuda sembrani

Aku hanya seorang prejurit yang patah hati

Seorang pandir yang kehilangan bahasa

dan tanah air. Seorang yang beriman

pada kesetiaan yang keras kepala

(Noor, 2017: 46)

Data diatas menunjukan penggunaan penggantian kata $a k u$ dengan kata seorang pandir hal tersebut dilakukan untuk memberikan unsur pembeda.

\section{Subtitusi Klausa} kesamaan.

Subtitusi klausa merupakan penggantian kata-kata dengan menunjukan

\section{Data 7}

Sebuahpulau bisa jadi hanya setitik tinta

Di tengah luasnya samudra. Begitu juga pulau ini

Pulau setitik tinta hijau ini tidak kelihatan dalam peta

Namun setiap lekuknya jelas tergambar di pelupuk mata

(Noor, 2017: 29)

Data diatas menunjukan penggunaan penggantian kata pulau dengan klausa pulau setitik tinta hijau hal tersebut dilakukan untuk memberikan unsur pembeda.

\section{c. Elipsis (pelesapan)}

Elipsis merupakan penghilangan kata yang bisa keluarkan kembali dalam pemahamannya. Berikut data penggunaannya.

\section{Data 8}

Tanpa terasa aku telah kehilangan semua jejakmu di bumi

Sebab pantai demi pantai tak pernah membuatku sampai

Langkah selalu terantuk pada tebing atau jurang itu juga

(Noor, 2017: 72)

Data di atas menunjukkan,pada kata juga merujuk pada tebing atau jurang. Kata tebing dan jurang di hilangan agar kalimatnya menjadi lebih pendek dan lebih baik susunannya.

\section{d. Konjungsi (kata hubung)}

Konjungsi digunakan dengan tujuan untuk menggabungkan kata beserta kata, frasa beserta frasa, klausa beserta klausa, kalimat beserta kalimat, dan paragraf beserta paragraf. Berikut data penggunaannya.

\section{Data 9}

Saat yang tepat untuk bertanya

Begitu juga musim yang tak jelas tabiatnya

yang bertukar posisi

(Noor, 2017: 22) 
Data di atas menunjukkan konjungsi subordinatif penghubung atribut, yaitu menggabungkan dua kata, frasa, dan klausa yang mempunyai status konjungsi bertingkat. Kata yang tergolong dalam konjungsi ini adalahyang.

\section{Data 10}

Dan rindu kenapa mesti disebut

Cinta dan rindu adalah pelangi senja

antara alis dan bulu mata

(Noor, 2017: 39)

Data di atas menunjukkan konjungsi aditif, yaitukonjungsi yang berfungsi untuk menghubungkan dua unsur gramatikal baik berupa kata, frasa, klausa, kalimat, dan paragraf. Kata yang masuk dalam konjungsi ini antara laindan, serta, lagipula.

\section{Data 11}

Ketika ombak berkejaran dengan sunyi

Dengan kuas sehalus awan pagi

Dengan pahat selentur jemari

(Noor, 2017: 40)

Data di atas menunjukkan konjungsi subordinatif penghubung cara, yaitu menghubungkan dua kata, frasa, klausa yang mempunyai status konjungsi bertingkat. Kata yang masuk dalam konjungsi ini adalahdengan, melalui.

\section{Data 12}

Deretan bukit seperti rangkaian gerbong kereta hantu

Yang meliuk-liuk mengikuti garis pantai

(Noor, 2017: 71)

Data di atas menunjukkan konjungsi penanda, berfungsi untuk menjelaskan perbuatan menandai terhadap sesuatu. Kata yang termasuk dalam konjungsi ini antara lain seperti, umpama, misalnya.

\section{Data 13}

Tanpa terasa aku telah kehilangan semua jejakmu di bumi

Sebab pantai demi pantai tak pernah membuatku sampai

(Noor, 2017: 72)

Data di atas menunjukkan konjungsi kausal, yang berfungsi menjelaskan penyebab suatu peristiwa tertentu. Kata yang termasuk dalam konjungsi ini adalahsebab, sebab itu, karena, karena itu.

\section{Piranti Kohesi Leksikal}

Kohesi leksikal merupakan hubungan antarunsur kalimat yang bersifat semantis dalam sebuah bentuk wacana. Wacana yang padu memerlukan pemilihan kata sesuai dengan isi kewacanaan tersebut. Sumarlam (2003) menyatakan bahwa kohesi leksikal dibagi menjadi enam macam yaitu: repetisi, sinonimi, antonimi, hiponimi, kolokasi, dan ekuivalensi.

\section{a. Repetisi (pengulangan)}

Repetisi atau seringkali disebut dengan pengulanganyaitu adanya pengulangan satuan lingual, baik itu adalah bunyi, suku kata, kata, atau bagian dari kalimat yang dianggap penting bertujuan untuk memberikan tekanan dalamsebuah konteks yang sesuai.

\section{Repetisi Anafora}

Repetisi anafora merupakan pengulangan satuan lingual kata maupun frasa pada awal baris atau kalimat. Berikut datanya.

\section{Data 14}

Tak lagi pergiharimu 
Taklagidatangmalammu

Waktulebihberhenti

Di tubuhmu

(Noor, 2017:16)

Data di atas menunjukkan repetisi anafora, terbukti pada kata Tak lagi yang mengalami perulangan di awal baris.

\section{Repetisi Epistrofora}

Repetisi epistrofora yaitu perulangan satuan bentuk lingual yang dapat berupa sebuah kata ataupun frasa yang terletak pada akhir baris kalimat, puisi, maupun prosa yang secara berturut-turut. Berikut datanya.

\section{Data 15}

Andai jemariku mengelus rambutmu

Aku hanya mengelus rambut waktu

Andai hanya mengelus rambut waktu

Sesungguhnya aku mengurai rahasia rindu

Andai mengurai rahasia rindu

Aku hanya mengungkapkannya lewat lagu

Andai hanya mengungkapkannya lewat lagu

Sesungguhnya aku lelah memeras seluruh jiwaku

(Noor, 2017: 41)

Data di atas termasuk jenis repetisi epistrofora, hal tersebut dibuktikan dengan adanya kata waktu, rindu, dan lagu yang mengalami perulangan di akhir baris puisi secara berturut-turut.

\section{Repetisi Mesodiplosis}

Repetisi mesodiplosis yaitu perulangan satuan lingual yang terletak pada tengah beberapa baris atau kalimat secara berturut-turut. Berikut datanya.

\section{Data 16}

Andai jemariku mengelus rambutmu

Aku hanya mengelus rambut waktu

Andai hanya mengelus rambut waktu

Sesungguhnya aku mengurai rahasia rindu

Andai mengurai rahasia rindu

Aku hanya mengungkapkannya lewat lagu

Andai hanya mengungkapkannya lewat lagu

Sesungguhnya aku lelah memeras seluruh jiwaku

(Noor, 2017:41)

Data di atas masuk dalam kelompok repetisi mesodiplosis, hal tersebut terbukti pada kata mengelus, mengurai, dan mengunkapkannya mengalami perulangan kata secara berturut-turut di tengah baris puisi. Sehingga ketika kata tersebut masuk dalam repetisi mesodiplosis.

\section{b. Sinonimi}

Sinonimi merupakan ungkapan baik sebuah kata, frasa, atau kalimat yang mempunyai makna kurang lebih sama.

\section{Sinonimi Kata dengan Kata}

Yaitu sebuah ungkapan berbentuk kata yang mempunyai makna yang sama. Berikut datanya.

\section{Data 17}

Tidak setiap senja aku bisa menemukan

Saat yang tepat untuk bertanya. Cuaca sulit diduga 
Begitu juga musim yang tak jelas tabiatnya

Menunggumu sebaiknya dijalani saja

(Noor, 2017:22)

Pada data di atas kata cuaca yang bersinonim dengan kata musim. Kedua kata tersebut dapat saling menggantikan tanpa adanya perubahan makna kalimat asalnya. Hal tersebut dapat dibuktikan arti kata tersebut dalam KBBI.

Menurut KBBI pengertian Cuaca merupakan suatu keadaan udara mengenai temperatur, cahaya matahari, kelembapan kecepatan angin, dan sebagainyadengan jangka waktu terbatas di suatu tempat tertentu. Sedangkan pengertian musim yaitu waktu tertentu yang berkaitan dengan keadaan iklim. Adanya pengertian kata diantara keduanya membuktikan bahwa kedua kata tersebut memiliki keterkaitan makna yang sama.

\section{Sinonimi Klausa atau Kalimat dengan Klausa atau Kalimat}

Yaitu sebuah ungkapan berbentuk klausa atau kalimat yang mempunyai makna yang sama. Berikut datanya.

\section{Data 18}

Kita menghanyutkan kenangan

Bersama segala limbah pertikaian

\section{Kita menenggelamkan semua ingatan}

Bersama reruntuk peradaban

(Noor, 2017:21)

Pada data puisi di atas, kata menghanyutkan kenangan bersinonim dengan menenggelamkan semua ingatan dalam bentuk klausa atau kalimat. Kedua klausa tersebut dikatakan sinonimi, karena keduanya mempunyai makna yang yang sama. Menurut KBBI kata menghanyutkan; berarti membawa hanyut, kenangan; berarti sesuatu yang membekas dalam ingatan. Sedangkan pada klausa atau kalimat menenggelamkan; berarti membenamkan ke dalam air, ingatan; berarti apa yang terbayang dalam ingatan. Dari pengertian kata menurut KBBI tersebut, keduanya jelas memiliki sinonim atau persamaan kata yang mempunyai makna yang sama.

c. Antonimi

Antonimi merupakan sebuah ungkapan baik berupa kata, frasa, klausa, atau kalimat, yang arti maknanya merupakan kebalikan dari makna yang diungkapkanatau dapat disebut sebagai lawan katanya. Berikut datanya.

\section{Data 19}

Di stasiun

\section{Kereta dating dan pergi}

Penumpang-penumpang berjejal

Menunggu jadwal

(Noor, 2017:48)

Data kata datang dan pergi di atas menunjukkan adanya hubungan antonimi. Hal tersebut dapat dibuktikan dengan pengertiannya menurut KBBI. Kata datang berati tiba di tempat yang dituju, sedangkan kata pergi berarti meninggalkan suatu tempat. Dari penjelasan KBBI di atas menunjukkan bahwa diantara kedua kata tersebut mempunyai makna atau arti yang berbeda (lawan kata) atau kebalikan kata antara satu dengan yang lain yang bertolak belakang sehingga dapat disimpulkan data tersebut merupakan antonimi.

\section{d. Hiponimi}


Hiponimi yaitu satuan bahasa yang mempunyai keterkaitan makna antara yang satu dengan yan lainnya sehingga maknanya merupakan bagian dari satuan lingual lainnya.

\section{Data 20}

Kereta datang dan pergi

Sebuah kapal melepas jangkar

\section{Pintu pesawat di buka}

(Noor, 2017:48)

Data di atas pada kata kereta, kapal, dan pesawat merupakan kata subordinat, sedangkan antasedennya yaitu transportasi sebagai superordinat. Relasi antara kedua kata tersebut adalah searah. Jadi kata kereta, kapal, dan pesawat berhiponim terhadap kata transportasi. Akan tetapi, kata transportasi tidak berhiponim terhadap kata kereta, kapal, dan pesawat, karena makna transportasi meliputi keseluruhan transportasi yang menjadi kelompoknya.

\section{e. Kolokasi}

Kolokasi merupakan adanya kumpulan tertentu dalam penggunaanya terdapat pilihan kata yang cenderung digunakan secara berdampingan, yaitu kata-kata yang serinkali diapakai dalam suatu domain atau jaringan tertentu. Berikut datanya.

\section{Data 21}

Siapakah yang menumpahkan biru

Ketika ombak berkejaran dengan sunyi

Siapakah yang menggambari langit

Dengan kuas sehalus awan pagi

(Noor, 2017:40)

Pada data di atas kata biru dan langit, keduanya berkolokasi. Hal tersebut dikarenakan kedua unsur tersebut diasosiasikan menjadi satu kesatuan. Kalau langit pastinya berwarna biru, sehingga keduanya merupakan satu kesatuan yang saling berhubungan. Jadi secara geografis kedua kata tersebut termasuk jenis kolokasi.

\section{f. Ekuivalensi (Kesepadanan)}

Ekuivalensi merupakan beberapa kata bentukan dari adanya sebuah proses afiksasi dari bentuk asal yang sama, ekuivalensi juga merupakan salah satu peranti untuk terbentuknya kepaduan wacana, Sumarlam(dalam Herianah, 2014).

\section{Data 22}

Tidak setiap senja aku mampu menerima

Kabar dari utara. Badai selaludatang dan pergi

Seperti kemarindan esok yang bertukar posisi

Hari ini kedatanganmu juga sebatas janji

(Noor, 2017:22)

Data di atas terdapat kata datang dan kedatanganmu, keduanya sama-sama memiliki kata dasar yaitu datang. Sehingga keduanya menunjukkan adanya kemiripan makna, atau mempunyai makna yang berdekatan. 


\section{SIMPULAN}

Berdasarkan analisis data piranti kohesi wacana pada Kumpulan Puisi "Berguru Kepada Rindu” Karya Acep Zamzam Noor. Terdapat dua piranti kohesi wacana yaitu piranti kohesi gramatikal dan kohesi leksikal. Piranti kohesi gramatikal yang ditemukan meliputi referensi (pengacuan), subtitusi (penggantian), elipsis (penghilangan atau pelepasan), dan konjungsi (penghubung). Sedangkan piranti kohesi leksikal yang ditemukan meliputi repetisi (pengulangan), sinonimi (persamaan kata), antonimi (lawan kata), hiponimi (hubungan atasbawah), kolokasi (sanding kata) dan ekuivalensi (kesepadanan kata). Namun, dari temuan data-data yang dianalisis, piranti kohesi yang paling dominan yang terdapat pada Buku Kumpulan Puisi "Berguru Kepada Rindu” Karya Acep Zamzam Noor adalah piranti kohesi leksikal. Hal ini dikarenakan dalam sebuah penulisan sebuah puisi lebih didominankan pada permainan kata-kata dan keterkaitan makna semantis suatu kata.

\section{DAFTAR PUSTAKA}

Badara, A. (2012). Analisis WACANA: Teori, Metode, dan Penerapannya pada Wacana Media. Jakarta: Kencana Prenada Media Group.

Herianah. (2014). Kohesi Gramatikal dan Leksikal dalam Wacana Puisi “Tadarusku Untukmu” Karya Sus S. Hardjono. Metalingua, 12(1), 57-69.

Mulyana. (2005). Kajian Wacana, Teori, Metode, dan Aplikasi Prinsip-prinsip Analisis Wacana. Yogyakarta: Tiara Wacana.

Sumarlam. (2003). Analisis Wacana: Teori dan Praktik. Surakarta: Pustaka Cakra. Sumarlam (ed). 2005. Analisis Wacana. Surakarta. UNS Press.

Noor, Acep Zamzam. 2017. Kumpulan Puisi Berguru kepada Rindu. Yogyakarta: DIVA Press

Purwitosari, A. (2010). Analisis Puisi Jawa dalam Harian Solopos Edisi Januari-Februari 2010. Universitas Muhammadiyah Surakarta, 3.

Romadhani, Ika Merry. 2016. Kohesi Gramatikal Pada Kumpulan Puisi Geladi Diri dan Implikasinya dalam Pembelajaran Bahasa di SMP. Surakarta: Publikasi Ilmiah.

Tarigan, Henry Guntur. 1987. Pengajaran Wacana. Bandung: Angkasa. 